Мамотенко Д.Ю., к. е. н, доцу. Запорізький національний технічний університет м. Запоріжжя, Україна

\title{
ДЕРЖАВНО-ПРИВАТНЕ ПАРТНЕРСТВО У СФЕРІ ТУРИЗМУ
}

Сьогодні у туристичній галузі України залишається багато невирішених проблем, які характеризуються суперечками між: об'єктивним прагненням регіональних органів влади підвищити економічну ефективність експлуатації об'єктів туристично-рекреаційного комплексу та відсутністю відповідного теоретичного осмислення економічних та управлінських механізмів, що дозволяють залучити інвестиції в галузь на цьому рівні; сучасними міжнародними тенденціями взаємодії держави і приватного сектора в туризмі і станом української галузевої нормативно-правової бази, що не в повному обсязі відповідає цим вимогам; необхідністю розвитку внутрішнього туризму, як елемента національної економіки, і явним експортним характером вітчизняної підприємницької діяльності в галузі туризму.

Вирішення цих суперечностей можливо при застосуванні концесійної системи державно-приватного партнерства (ДПП), що об'єднує необхідну інфраструктуру до єдиного туристично-рекреаційного комплексу, який здатний виробляти і реалізовувати конкурентоспроможний туристичний продукт під єдиним управлінням, в найкоротші терміни і з мінімальними витратами.

Варто зазначити: наразі у світі налічується більше 100 проектів державно-приватного партнерства, що реалізовані у сферах, пов'язаних із туризмом. Проекти ДППТ реалізовуються у країнах усіх регіонів світу, із різним рівнем економічного розвитку та туристичним потенціалом. Деякі 3 проектів орієнтовані на розвиток туризму по країні в цілому (проекти ДППТ у Таїланді, Австралії, Непалі, країнах Карибського басейну, Канаді, Гані), інші - на розвиток певних дестинацій та (або) певних видів туризму на їхніх територіях (Кіпр, затока Акаба, національні парки тощо). Існують й такі, що стосуються розвитку певного об'єкта туристичної привабливості (готель «Armada» у м. Стамбул, тематичний парк «Диснейленд» у м. Париж) [1]. 
Європейська економічна комісія $\mathrm{OOH}$ розглядає ДПП як один із ключових інструментів досягнення Цілей сталого розвитку до 2030 року, тому Україні дуже важливо розробити актуальну законодавчу базу у цій сфері.

В Україні дані взаємовідносини держави та приватного сектора в галузі туризму регулюються законом України від 1999 року «Про концесії» [2], який визначає концесію у більш широкому колі відповідальності та функцій приватної сторони. Для удосконалення державно-приватного партнерства створено законопроект «Про концесії», який Мінекономрозвитку розробило разом з СБРР та міжнародними консультантами [3]. Він систематизує чотири чинні закони України, що регулюють здійснення концесійної діяльності, і дозволить запровадити найкращий міжнародний досвід в Україні.

Згідно із законопроектом, строк концесії може становити від 3 до 50 років. Ініціаторами концесії можуть виступати органи державної влади, які здійснюють управління об'єктами державної власності, органи місцевого самоврядування чи юридичні особи приватного права (резиденти та/або нерезиденти). Контроль за здійсненням концесії можуть виконувати концесієдавець, Мінекономрозвитку, інші державні органи та органи місцевого самоврядування. Щоб уникнути необ'єктивності, завершальну оцінку здійснює центральний орган виконавчої влади, уповноважений Кабінетом Міністрів, який не брав участь у здійсненні концесії, включаючи стадію підготовки [3].

Отже, туристська концесія являє собою передачу концесіонеру одного або декількох (в комплексі) природних, історичних, соціальнокультурних об'єктів, що належать державі, включаючи об'єкти туристського показу, а також інші об'єкти, передбачені концесійним законодавством, для будівництва, модернізації, реконструкції, експлуатації, управління та обслуговування на певних, закріплених у договорі умовах, але виключно в туристських цілях.

Оновлене концесійне законодавство відкриє нові можливості для залучення інвестицій та сприятиме втіленню масштабних проектів в туристичній сфері України. Доцільно говорити про туристські концесійні угоди як про самостійний вигляд партнерства.

\section{Список бібліографічних посилань}

1. Лісіцина I. I. Державно-приватне партнерство в галузі туризму: зарубіжний досвід . БІЗНЕС ІНФОРМ. 2013. № 11. С. 196-203.

2. Про концесії: Закон України від 16.07.1999 № 997-XIV. Дата оновлення: 25.03.2018. URL : https://zakon.rada.gov.ua/laws/show/ 997-14 (дата звернення: 11.02.2019).

3. Проект Закону «Про концесії». URL: http:/w1.c1.rada.gov.ua/pls/ zweb2/webproc4_1?pf3511=63630 (дата звернення: 11.02.2019). 